\title{
УДК 005.931.11
}

\section{СИСТЕМА ОЦНЮВАННЯ ФІНАНСОВОЇ СТІЙКОСТІ СУБ'ЄКТІВ ГОСПОДАРЮВАННЯ В УМОВАХ ГЛОБАЛЬНИХ ВИКЛИКІВ}

\author{
Марина Татар; Олена Гребенікова
}

\author{
Національний аерокосмічний університет імені М. С. Жуковського \\ «Харківський авіаційний інститут», Харків, Украӥна
}

\begin{abstract}
Резюме. Актуалізовано необхідність забезпечення фінансової стійкості суб'єктів господарювання в умовах глобальних викликів. Визначено, щзо фінансова стійкість підприємства є однією з найважливіших характеристик фінансового стану підприємства, пов'язана з рівнем залежності від кредиторів та інвесторів і характеризується співвідноменням власних $i$ залучених коштів. Проаналізовано існуючі методичні підходи до оцінювання фінансової стійкості підприємства. Здійснено оиінювання фінансової стійкості на прикладі металургійного підприємства за коефіиієнтним, бальним та інтегральним методами. Коефіцієнтний аналіз показав, щзо більшість коефіцієнтів фінансової стійкості в динаміці погіршилася й знаходилася не в межах нормативних значень. У прочесі аналізу типу фінансової стійкості визначено, щэо досліджуване підприємство у 2018-2020 рр. мало нестійкий фінансовий стан, щяо свідчить про порушення платоспроможності. Результати аналізу фінансової стійкості за бальним методом, згідно з яким коефіцієнтам присвоюється відповідний бал залежно від наближення до нормативного показника, дозволили дійти висновку, щзо ПРАТ «МК «АЗОВСТАЛЬ» у 2018-2020 рр. належало до n'ятого класу-кризове підприємство найвищого рівня ризику, практично не платоспроможне. Проведене оиінювання фінансової стійкості за інтегральним методом, згідно з яким значення інтегрального показника має наближатися до одиниці, показало, щчо фінансова стійкість досліджуваного підприємства у 2018 р. поганою, у 2019 р.- дуже поганою, а в 2020 р. - задовільною. Запропоновано заходи підвищення фінансової стійкості підприємств залежно від рівня фінансової стійкості. Зокрема для досліджуваного підприємства пропонується покращення планування фінансових потоків, введення в дію реальних платіжних календарів, створення центрів фінансової відповідальності та посилення контролю за ними з боку холдингу, щзо дозволить завжди мати в наявності достовірну інформацію про грошові потоки підприємства та підвищити контрольованість поточних платежів, знизити втрати від нецільового використання коштів. Також запропоновано пришвидшення оборотності ресурсів підприємства, що покращить загальну ефективність діяльності.
\end{abstract}

Ключові слова: глобальні виклики, методичні підходи, оцінювання, суб'єкти господарювання, фінансова стійкість.

https://doi.org/10.33108/galicianvisnyk_tntu2021.04.020

Отримано 13.07.2021

\section{UDC 005.931.11}

\section{SYSTEM FOR EVALUATION OF BUSINESS ENTITIES FINANCIAL SUSTAINABILITY UNDER GLOBAL CHALLENGES CONDITIONS}

\section{Maryna Tatar; Olena Hrebenikova}

\section{National Aerospase University «Kharkiv Aviation Institute», Kharkiv, Ukraine}

Summary. The need to ensure financial stability of businesses under global challenges conditions is highlighted in this paper. The company financial stability is one of the most important characteristics of the company financial condition, associated with the level of dependence on creditors and investors and is characterized by the ratio of equity and liabilities. The existing methodological approaches for the evaluation 
of the enterprise financial stability are analyzed. The evaluation of financial stability on the example of metallurgical enterprise by coefficient, score and integrated methods is carried out. The coefficient analysis shows that the most of financial stability coefficients in the dynamics have decreased and are not within the normative values. While analyzing the financial stability type, it is determined that the enterprise in 2018-2020 had unstable financial condition, which indicates solvency violation. The results of the financial stability analysis by scoring method, according to which the coefficients are assigned the appropriate score depending on the approximation to the normative indicator, led to the conclusion that PJSC "AZOVSTAL» in 2018-2020 was included to the fifth class, i.e. crisis enterprise of the highest risk, practically not solvent. The evaluation of financial stability by the integrated method, according to which the value of the integrated indicator should be closer to one, showed that the enterprise financial stability in $2018 \mathrm{was}$ bad, in 2019 very bad, and in 2020 satisfactory. The measures to increase the enterprises financial stability depending on the financial stability level are proposed, particularly, for the investigated enterprise it is proposed to improve financial flow planning, implementation of real payment calendars, creation of financial responsibility centers and strengthening control over them by the holding, which always make it possible to have reliable information about the company's cash flows and increase the controllability of current payments, reduce loss es from the funds misuse. It is also proposed to accelerate the turnover of enterprise resources, which will improve the overall efficiency of activities. stability.

Key words: global challenges, methodological approaches, evaluation, business entities, financial

Постановка проблеми. Сьогодні функціонування підприємств здійснюється в складних умовах, які супроводжуються наявністю різноманітних глобальних економічних, геополітичних, соціальних, біологічних, природно-кліматичних, інформаційних, культурних та інших викликів [1], що вимагає максимальної мобілізації наявних ресурсів, здатності пристосовуватися до різних ситуацій, достатньої гнучкості у прийнятті рішень. В умовах глобальних викликів зростає важливість забезпечення фінансової стійкості суб'єктів господарювання, що є необхідною передумовою для безперебійного здійснення всіх напрямів діяльності, забезпечення можливості залучення інвестицій і здатності динамічно розвиватися на інноваційних засадах.

Аналіз останніх досліджень і публікацій. Проблематику оцінювання та забезпечення фінансової стійкості підприємств висвітлювали у своїх працях науковці А. Ю. Войтенко [2], І. О. Геращенко [2], О. М. Гізатулліна [3], С. Я. Слецьких [4], Ю. С. Копчак [5], І. П. Косарєва [6], О. С. Патута [7], К. С. Пришко [7], А. М. Поддєрьогін [8], Н. М. Притуляк [9], Рудницька О. М. [10], О. М. Тридід [11] та багато інших. Однак незважаючи на значну кількість та різноплановість напрацювань дослідників актуальним є оцінювання фінансової стійкості підприємства та розроблення заходів їі підвищення, що особливо актуально для бюджетоутворюючих підприємств України в умовах глобальних викликів.

Мета статті - проведення аналізу теоретико-методичних і практичних аспектів оцінювання фінансової стійкості підприємства та розроблення заходів ії підвищення.

Постановка завдання. Досягнення поставленої мети передбачає вирішення таких завдань: проаналізувати методики оцінювання фінансової стійкості промислового підприємства; здійснити оцінювання фінансової стійкості металургійного підприємства за коефіцієнтним, бальним та інтегральним методами; розробити заходи підвищення рівня фінансової стійкості ПРАТ «МК«АЗОВСТАЛЬ».

Виклад основного матеріалу. Одним із етапів управління стійкістю є її кількісне та якісне оцінювання. Для проведення оцінювання фінансової стійкості підприємства запропоновано процесну модель, наведену на рис. 1. 


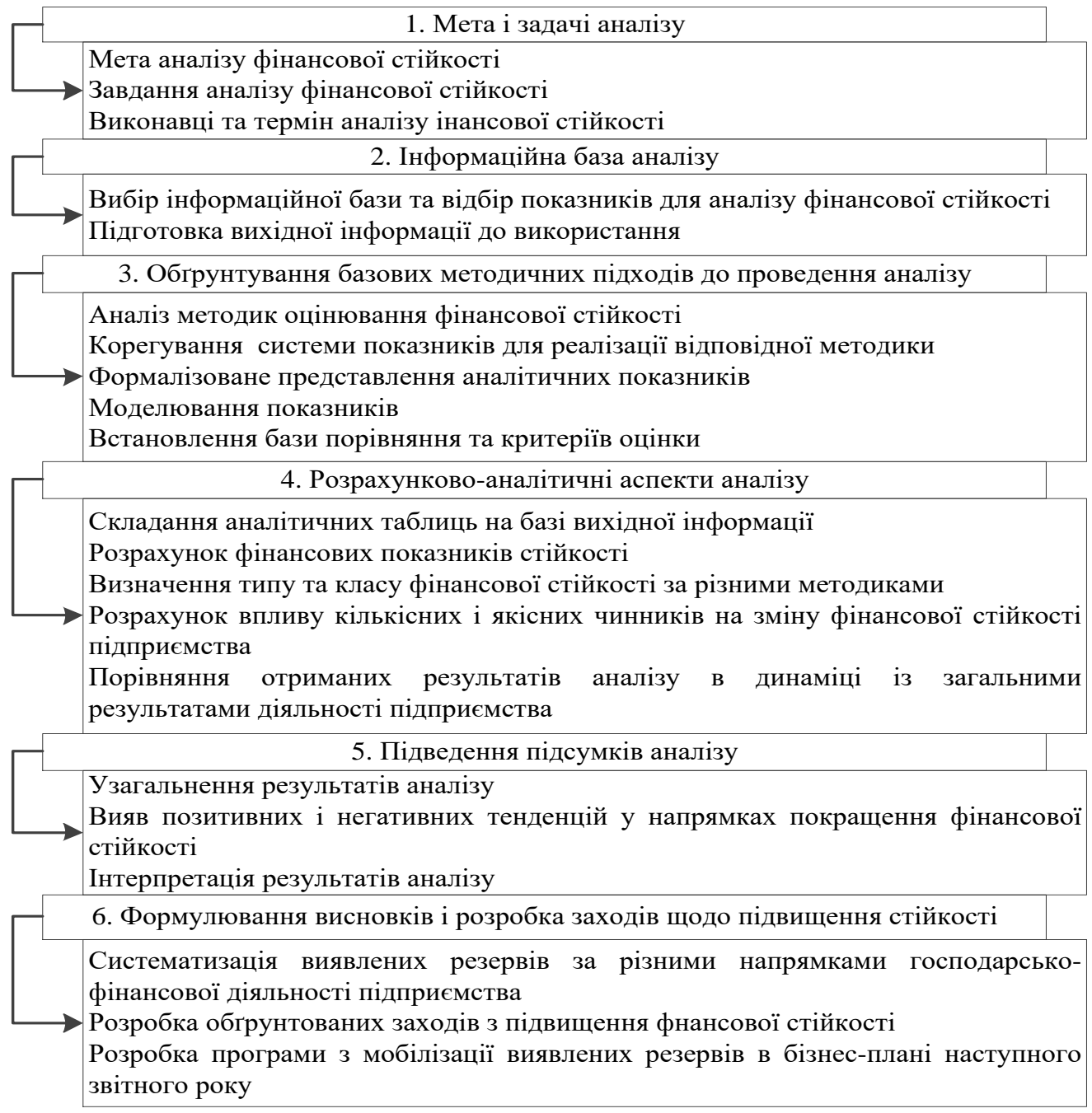

Рисунок 1. Модель оцінювання фінансової стійкості підприємства

Figure 1. Model of enterprise financial stability evaluation

Джерело: побудовано авторами на підставі [4].

Таблиця 1. Методичні підходи до оцінки фінансової стійкості підприємства

Table 1. Methodical approaches to the evaluation of the enterprise financial stability

\begin{tabular}{|c|c|c|}
\hline Назва підходу & Сутність & Результат оцінювання \\
\hline 1 & 2 & 3 \\
\hline $\begin{array}{l}\text { Агрегатний } \\
\text { підхід }\end{array}$ & $\begin{array}{l}\text { Аналіз абсолютних показників } \\
\text { стійкості }\end{array}$ & Визначення типу фінансової стійкості \\
\hline $\begin{array}{l}\text { Коефіцієнтний } \\
\text { підхід }\end{array}$ & $\begin{array}{l}\text { Аналіз відносних показників фінансової } \\
\text { стійкості та їх порівняння } 3 \text { нормативними } \\
\text { значеннями }\end{array}$ & $\begin{array}{l}\text { Визначення реального фінансового } \\
\text { стану, слабких і сильних сторін } \\
\text { діяльності підприємства }\end{array}$ \\
\hline $\begin{array}{c}\text { Маржинальний } \\
\text { підхід }\end{array}$ & $\begin{array}{l}\text { Розрахунок порогу рентабельності за } \\
\text { допомогою поділу затрат на постійні і змінні та } \\
\text { використання маржинального доходу }\end{array}$ & Визначення запасу фінансової стійкості \\
\hline Бальний підхід & $\begin{array}{l}\text { Додавання коефіцієнтів ліквідності до складу } \\
\text { показників у бальній } \\
\text { стійкості }\end{array}$ & Визначення класу фінансової стійкості \\
\hline
\end{tabular}


Закінчення таблиці 1

\begin{tabular}{|c|l|l|}
\hline 1 & \multicolumn{1}{|c|}{2} & \multicolumn{1}{|c|}{3} \\
\hline $\begin{array}{c}\text { Балансовий } \\
\text { підхід }\end{array}$ & Використання балансової моделі & $\begin{array}{l}\text { Оцінка фінансової стійкості виходячи зі } \\
\text { ступеня покриття Запасів та основних } \\
\text { засобів джерелами фінансування }\end{array}$ \\
\hline $\begin{array}{c}\text { Iнтегральний } \\
\text { підхід }\end{array}$ & $\begin{array}{l}\text { Інтегральне оцінювання ступеня фінансової } \\
\text { стійкості 3 використанням узагальнюючого } \\
\text { показника зміни фінансової стійкості }\end{array}$ & $\begin{array}{l}\text { Визначення ступеня фінансової стій- } \\
\text { кості та виявлення їїдинаміки }\end{array}$ \\
\hline $\begin{array}{c}\text { Факторний } \\
\text { підхід }\end{array}$ & $\begin{array}{l}\text { Проведення факторного аналізу фінансової } \\
\text { стійкості, який включає побудову ланцюга } \\
\text { показників та аналіз їх темпів зростання }\end{array}$ & $\begin{array}{l}\text { Визначення рангу показників, який } \\
\text { дозволить сформувати висновок про } \\
\text { фінансовий стан підприємства }\end{array}$ \\
\hline $\begin{array}{c}\text { Матричний } \\
\text { підхід }\end{array}$ & Складання матричних балансів & $\begin{array}{l}\text { Розрахунок структури й визначення } \\
\text { якості активів балансу та достатності } \\
\text { джерелі іх фінансування }\end{array}$ \\
\hline
\end{tabular}

Джерело: складено авторами на підставі $[2,11]$.

ПРАТ «МК» АЗОВСТАЛЬ» - металургійний комбінат, монополіст в Україні з випуску деяких видів металопрокату, підприємство з повним металургійним циклом. За рівнем валового доходу займає 3-є місце серед металургійних підприємств України. Продукція поставляється в регіони України, а також відвантажується на експорт. Продажі за видами продукції наведено в табл. 2.

Таблиця 2. Продажі за видами продукції

Table 2. Sales by product type

\begin{tabular}{|c|c|c|c|c|c|c|}
\hline Період & Сляби & Листовий прокат & Сортовий прокат & $\begin{array}{c}\text { Інші товари (вугілля, } \\
\text { кокс тощо) }\end{array}$ & Інше & Усього \\
\hline 2018 & 34753768 & 15136971 & 9363299 & 19049437 & 3657401 & 81960876 \\
\hline 2019 & 28270951 & 12423102 & 7070929 & 7925508 & 1602646 & 57293136 \\
\hline 2020 & 28995857 & 9528214 & 7596808 & 2257300 & 2185075 & 50563254 \\
\hline
\end{tabular}

Джерело: розроблено авторами на підставі [12].

Показники, що характеризують фінансову стійкість поділяються на абсолютні та відносні. Відносні показники наведено в табл. 3.

Таблиця 3. Показники фінансової стійкості підприємства

Table 3. Indicators of the enterprise financial stability

\begin{tabular}{|c|c|c|}
\hline Показник & Розрахункова формула & $\begin{array}{c}\text { Нормативне } \\
\text { значення }\end{array}$ \\
\hline 1 & 2 & 3 \\
\hline \multicolumn{3}{|c|}{ Показники структури капіталу } \\
\hline Коефіцієнт автономії (незалежності) & Власний капітал/Пасиви & $\geq 0,5$ \\
\hline $\begin{array}{l}\text { Коефіцієнт концентрації залученого } \\
\text { капіталу }\end{array}$ & Зобов’язання/Пасиви & $<0,5$ \\
\hline Коефіцієнт фінансової стабільності & Власний капітал/Зобов'язання & $\geq 1$ \\
\hline Коефіцієнт фінансового ризику & Зобов’язання/Власний капітал & $<1$ \\
\hline $\begin{array}{l}\text { Коефіцієнт довготермінового залучення } \\
\text { позикових коштів }\end{array}$ & $\begin{array}{l}\text { Довготермінові зобов’язання/[Власний } \\
\text { капітал]+[Довготермінові зобов'язання] }\end{array}$ & Зменшення \\
\hline Коефіцієнт структури залученого капіталу & $\begin{array}{c}\text { Довготермінові } \\
\text { зобов'язання/Зобов'язання }\end{array}$ & Збільшення \\
\hline
\end{tabular}


Система оцінювання фінансової стійкості суб’єктів господарювання в умовах глобальних викликів

Закінчення таблиці 3

\begin{tabular}{|c|c|c|}
\hline 1 & 2 & 3 \\
\hline \multicolumn{3}{|c|}{ Показники стану оборотних активів } \\
\hline Коефіцієнт маневреності власного капіталу & $\begin{array}{c}\text { Власні оборотні кошти/ Власний } \\
\text { капітал }\end{array}$ & Збільшення \\
\hline $\begin{array}{l}\text { Коефіцієнт забезпеченості оборотних } \\
\text { коштів }\end{array}$ & Власні оборотні кошти/Оборотні активи & $\geq 0,1$ \\
\hline Коефіцієнт забезпеченості запасів & Власні оборотні кошти/Запаси & $\geq 0,5$ \\
\hline $\begin{array}{l}\text { Коефіцієнт маневреності власних } \\
\text { оборотних коштів }\end{array}$ & Грошові кошти/Власні оборотні кошти & Збільшення \\
\hline \multicolumn{3}{|c|}{ Показники стану основного капіталу } \\
\hline Коефіцієнт реальної вартості майна & [Основні засоби]+[Запаси]/ Активи & Збільшення \\
\hline $\begin{array}{l}\text { Коефіцієнт реальної вартості основних } \\
\text { засобів у майні }\end{array}$ & Основні засоби/Активи & Збільшення \\
\hline Коефіцієнт накопичення амортизації & $\begin{array}{c}\text { Знос основних засобів і нематеріальних } \\
\text { активів/Первісна вартість основних } \\
\text { засобів і нематеріальних активів }\end{array}$ & Зменшення \\
\hline $\begin{array}{l}\text { Коефіцієнт співвідношення оборотних і } \\
\text { необоротних активів }\end{array}$ & Оборотні активи/Необоротні активи & Збільшення \\
\hline
\end{tabular}

Примітка. Джерело: складено авторами на підставі [5, 7, 8].

Результати розрахунку показників фінансової стійкості ПРАТ «МК «АЗОВСТАЛЬ» за 3 роки наведено у табл. 4.

Таблиця 4. Показники фінансової стійкості ПРАТ «МК «АЗОВСТАЛЬ»

Table 4. Indicators of PJSC «AZOVSTAL» financial stability

\begin{tabular}{|c|c|c|c|}
\hline \multirow{2}{*}{ Показник } & \multicolumn{3}{|c|}{ Значення за роками } \\
\hline & 2018 & 2019 & 2020 \\
\hline \multicolumn{4}{|c|}{ Показники структури капіталу } \\
\hline Коефіцієнт автономії, або фінансової незалежності & 0,33 & 0,30 & 0,33 \\
\hline Коефіцієнт концентрації залученого капіталу & 0,67 & 0,70 & 0,67 \\
\hline Коефіцієнт фінансової стабільності & 0,49 & 0,42 & 0,48 \\
\hline Коефіцієнт фінансового ризику & 2,05 & 2,37 & 2,07 \\
\hline Коефіцієнт довготермінового залучення позикових коштів & 0,13 & 0,15 & 0,16 \\
\hline Коефіцієнт структури залученого капіталу & 0,07 & 0,08 & 0,09 \\
\hline \multicolumn{4}{|c|}{ Показники стану оборотних активів } \\
\hline Коефіцієнт маневреності власного капіталу & $-0,02$ & $-0,51$ & $-0,42$ \\
\hline Коефіцієнт забезпеченості оборотних коштів & $-0,01$ & $-0,27$ & $-0,25$ \\
\hline Коефіцієнт забезпеченості запасів & $-0,07$ & $-2,00$ & $-1,92$ \\
\hline Коефіцієнт маневреності власних оборотних коштів & $-1,18$ & $-0,03$ & $-0,12$ \\
\hline \multicolumn{4}{|c|}{ Показники стану основного капіталу } \\
\hline Коефіцієнт реальної вартості майна & 0,40 & 0,44 & 0,48 \\
\hline Коефіцієнт реальної вартості основних засобів у майні & 0,27 & 0,35 & 0,41 \\
\hline Коефіцієнт накопичення амортизації & 0,19 & 0,04 & 0,13 \\
\hline Коефіцієнт співвідношення оборотних і необоротних активів & 1,98 & 1,24 & 1,16 \\
\hline
\end{tabular}

Джерело: розраховано авторами на підставі [12]. 
Методику розрахунку типу фінансової стійкості наведено в табл. 5.

Таблиця 5. Визначення типу фінансової стійкості ПРАТ «МК «АЗОВСТАЛЬ» (станом на кінець року)

Table 5. Determination of the type of PJSC «AZOVSTAL» financial stability (the end of the year)

\begin{tabular}{|c|l|c|c|c|}
\hline \multirow{2}{*}{ Ч.ч. } & \multicolumn{1}{|c|}{ Показники } & \multicolumn{3}{c|}{ Значення за роками } \\
\cline { 3 - 5 } & \multicolumn{1}{|c|}{} & 2018 & 2019 & 2020 \\
\hline 1 & Власний капітал (ВК) & 30062761 & 23000920 & 23313106 \\
\hline 2 & Необоротні активи (НА) & 30800401 & 34631296 & 33093859 \\
\hline 3 & Власні оборотні кошти (ВОК=ВК-НА) & -737640 & -11630376 & -9780753 \\
\hline 4 & Довготермінові зобов’язання (ДЗ) & 4364028 & 4364028 & 4514610 \\
\hline 5 & $\begin{array}{l}\text { Короткотермінові кредити банків і кредиторська } \\
\text { заборгованість за товари, роботи, послуги (КК) }\end{array}$ & 48926756 & 43028379 & 36734104 \\
\hline 6 & Запаси і витрати & 11894201 & 7074002 & 6328644 \\
\hline 7 & Наявність ВОК і ДЗ для формування запасів & 3626388 & -7266348 & -5266143 \\
\hline 8 & Наявність ВОК, ДЗ і КК для формування запасів & 52553144 & 35762031 & 31467961 \\
\hline 9 & $\begin{array}{l}\text { Надлишок (+) або нестача (-) ВОК для формування } \\
\text { запасів }\end{array}$ & -12631841 & -18704378 & -16109397 \\
\hline 10 & $\begin{array}{l}\text { Надлишок (+) або нестача (-) ВОК і ДЗ для формування } \\
\text { Запасів }\end{array}$ & -8267813 & -14340350 & -11594787 \\
\hline 11 & $\begin{array}{l}\text { Надлишок (+) або нестача (-)ВОК, ДЗ і КК для } \\
\text { формування запасів }\end{array}$ & 40658943 & 28688029 & 25139317 \\
\hline 12 & Тип фінансової стійкості & Нестійкий & Нестійкий & Нестійкий \\
\hline
\end{tabular}
Джерело: розраховано авторами за даними [12].

На основі групування активів та пасивів розраховано показники ліквідності та платоспроможності станом на кінець року (табл. 6).

Таблиця 6. Результати розрахунку показників платоспроможності ПРАТ «МК «АЗОВСТАЛЬ»

Table 6. The results of the calculation of PJSC «AZOVSTAL» solvency ratios

\begin{tabular}{|l|c|c|c|c|}
\hline \multirow{2}{*}{ Показник } & \multicolumn{3}{c|}{ Значення за роками } & \multirow{2}{*}{ Нормативне значення } \\
\cline { 2 - 4 } & 2018 & 2019 & 2020 & \\
\hline Коефіцієнт абсолютної ліквідності & 0,0153 & 0,0075 & 0,0268 & $0,05<$ К абс $<0,2$ \\
\hline Коефіцієнт швидкої ліквідності & 0,9881 & 0,8494 & 0,7628 & $0,7 \ldots 0,8<$ Кшв $<1,5$ \\
\hline Коефіцієнт покриття & 1,0634 & 0,8525 & 0,8796 & $1 \ldots 2<$ Кп $<2 \ldots 3$ \\
\hline Коефіцієнт загальної платоспроможності & 1,4882 & 1,4213 & 1,4832 & Збільшення \\
\hline
\end{tabular}

Джерело: розраховано авторами за даними [12].

Отримані результати показують, що у 2020 р. коефіцієнт абсолютної ліквідності був нижче нормативного значення. Коефіцієнт швидкої ліквідності знижувався упродовж років, однак був у межах нормативних значень. Коефіцієнт покриття у 20192020 рр. нижче нормативного значення.

Окрім аналізу показників фінансової стійкості й визначення типу фінансової стійкості, пропонується визначення класу фінансової стійкості промислового підприємства за бальною методикою, згідно 3 якою коефіцієнтам присвоюється відповідний бал залежно від наближення до нормативного показника. Розрахунок бального методу оцінювання фінансової стійкості наведено в табл. 7. 
Таблиця 7. Класифікація бального методу оцінювання фінансової стійкості

Table 7. Classification of the scoring method for financial stability evaluation

\begin{tabular}{|c|c|c|c|c|c|c|}
\hline \multirow{3}{*}{\begin{tabular}{l}
\multicolumn{1}{c}{ Показник } \\
$\begin{array}{l}\text { Коефіцієнт } \\
\text { абсолютної ліквідності }\end{array}$
\end{tabular}} & \multicolumn{6}{|c|}{ Границі класів відповідно до критеріїв } \\
\hline & \multirow{2}{*}{$\begin{array}{c}\text { I клас } \\
0,5 \text { i > = } \\
20 \text { балів }\end{array}$} & \multirow{2}{*}{$\begin{array}{l}\text { II клас } \\
0,4 \text { i > = } \\
16 \text { балів }\end{array}$} & \multirow{2}{*}{$\begin{array}{c}\text { III клас } \\
0,3= \\
12 \text { балів }\end{array}$} & \multirow{2}{*}{$\begin{array}{c}\text { IV клас } \\
0,2= \\
8 \text { балів }\end{array}$} & \multicolumn{2}{|c|}{ V клас } \\
\hline & & & & & $\begin{array}{c}0,1= \\
4 \text { бали }\end{array}$ & $\begin{aligned} & <0,1 \\
= & 0 \text { балів }\end{aligned}$ \\
\hline $\begin{array}{l}\text { Коефіцієнт швидкої } \\
\text { ліквідності }\end{array}$ & $\begin{array}{l}1,5 \mathrm{i}>= \\
18 \text { балів }\end{array}$ & $\begin{array}{c}1,4= \\
15 \text { балів }\end{array}$ & $\begin{array}{c}1,3= \\
12 \text { балів }\end{array}$ & $\begin{array}{l}1,2: 1,1= \\
9: 6 \text { балів }\end{array}$ & $\begin{array}{c}1,0= \\
3 \text { бали }\end{array}$ & $\begin{aligned} & <0,1 \\
= & 0 \text { балів }\end{aligned}$ \\
\hline $\begin{array}{l}\text { Коефіцієнт поточної } \\
\text { ліквідності }\end{array}$ & $\begin{array}{c}2 \mathrm{i}>= \\
16,5 \text { балів }\end{array}$ & $\begin{array}{c}1,9: 1,7= \\
15: 12 \text { балів }\end{array}$ & $\begin{array}{c}1,6: 1,4= \\
10,5: 7,5 \\
\text { балів }\end{array}$ & $\begin{array}{c}1,3: 1,1= \\
6,6: 1,8 \\
\text { балів }\end{array}$ & $\begin{array}{c}0,4: 1= \\
1 \text { бал }\end{array}$ & $\begin{array}{c}<0,4=0 \\
\text { балів }\end{array}$ \\
\hline Коефіцієнт автономії & $\begin{aligned} & 0,6 \mathrm{i}> \\
= & 17 \text { балів }\end{aligned}$ & $\begin{array}{c}0,59: 0,54= \\
16,2: 12,2 \\
\text { балів } \\
\end{array}$ & $\begin{array}{c}0,53: 0,43= \\
11,4: 7,4 \\
\text { балів } \\
\end{array}$ & $\begin{array}{c}0,47: 0,41= \\
6,6: 1,8 \\
\text { балів } \\
\end{array}$ & $\begin{array}{l}0,4= \\
1 \text { бал }\end{array}$ & $\begin{aligned} & <0,4 \\
= & 0 \text { балів }\end{aligned}$ \\
\hline $\begin{array}{l}\text { Коефіцієнт } \\
\text { забезпечення ВОК }\end{array}$ & $\begin{array}{l}0,5 \mathrm{i}>= \\
15 \text { балів }\end{array}$ & $\begin{array}{c}0,4= \\
12 \text { балів }\end{array}$ & $\begin{array}{c}0,3= \\
9 \text { балів }\end{array}$ & $\begin{array}{c}0,2= \\
6 \text { балів }\end{array}$ & $\begin{array}{c}0,1= \\
3 \text { бали }\end{array}$ & $\begin{aligned} & <0,1 \\
= & 0 \text { балів }\end{aligned}$ \\
\hline $\begin{array}{l}\text { Коефіцієнт фінансової } \\
\text { незалежності в частині } \\
\text { формування запасів і } \\
\text { витрат }\end{array}$ & $\begin{array}{c}1 \mathrm{i}>= \\
13,5 \text { балів }\end{array}$ & $\begin{array}{c}0,9=11 \\
\text { балів }\end{array}$ & $\begin{array}{c}0,8= \\
8,5 \text { балів }\end{array}$ & $\begin{array}{c}0,7: 0,6= \\
6,0: 3,5 \\
\text { балів }\end{array}$ & $\begin{array}{l}0,5= \\
1 \text { бал }\end{array}$ & $\begin{aligned} & <0,5 \\
= & 0 \text { балів }\end{aligned}$ \\
\hline $\begin{array}{l}\text { Мінімальне } \\
\text { значення }\end{array}$ & $100: 85,3$ & $85,2: 63,5$ & $63,4: 56,5$ & $56,4: 28,3$ & $14: 28,2$ & $0: 14$ \\
\hline
\end{tabular}

Джерело: складено авторами на підставі [10].

Бали за відповідними показниками підсумовуються й підприємству присвоюється відповідний клас, за яким визначається сукупний рівень фінансової стійкості й довготермінової платоспроможності (табл. 8).

Таблиця 8. Характеристика класів

Table 8. Classes characteristics

\begin{tabular}{|c|l|}
\hline Клас & \multicolumn{1}{|c|}{ Характеристика } \\
\hline I клас & $\begin{array}{l}\text { Фінансово абсолютно стійке підприємство, кредити якого підкріплені інформацією, } \\
\text { яка дозволяє бути впевненим у поверненні боргів та виконанні зобов'язань у } \\
\text { відповідності з договором. Ліквідність та платоспроможність перебуває у нормальному } \\
\text { стані }\end{array}$ \\
\hline II клас & $\begin{array}{l}\text { Підприємство 3 нормальною фінансовою стійкістю, яке демонструє невисокий рівень } \\
\text { ризику за кредитами та зобов'язаннями. Підприємства даного класу не розглядаються } \\
\text { як ризикові. Платоспроможність та ліквідність підприємства перебуває у нормальному } \\
\text { стані }\end{array}$ \\
\hline III клас & $\begin{array}{l}\text { Фінансово нестійке підприємство, на якому не передбачається втрата засобів, проте повне } \\
\text { погашення процентів при виконанні зобов'язань сумнівним }\end{array}$ \\
\hline IV клас & Передкризовий стан, присутній ризик втрати платоспроможності \\
\hline V клас & Кризове підприємство найвищого рівня ризику, практично не платоспроможне \\
\hline
\end{tabular}
Джерело: складено авторами на підставі [10].

Результати розрахунку коефіцієнтів для застосування методики бального оцінювання та визначення балів залежно від значень показників наведено в таблиці 9. 
Таблиця 9. Результати оцінювання показників фінансової стійкості ПРАТ «МК «АЗОВСТАЛЬ»

Table 9. Results of evaluation of PJSC «AZOVSTAL» financial stability indicators

\begin{tabular}{|l|c|c|c|c|c|c|}
\hline \multirow{2}{*}{\multicolumn{1}{|c|}{ Показник }} & \multicolumn{5}{c|}{ Значення за роками } \\
\cline { 2 - 7 } & \multicolumn{2}{c|}{2018} & \multicolumn{2}{c|}{2019} & \multicolumn{2}{c|}{2020} \\
\cline { 2 - 7 } & Значення & Бал & Значення & Бал & Значення & Бал \\
\hline Коефіцієнт абсолютної ліквідності & 0,0153 & 0 & 0,0075 & 0 & 0,0268 & 0 \\
\hline Коефіцієнт швидкої ліквідності & 0,9881 & 3 & 0,8494 & 3 & 0,7628 & 3 \\
\hline Коефіцієнт покриття & 1,0634 & 1,8 & 0,8525 & 1 & 0,8796 & 1 \\
\hline Коефіцієнт автономії (незалежності) & 0,3280 & 0 & 0,2964 & 0 & 0,3258 & 0 \\
\hline Коефіцієнт забезпечення ВОК & $-0,0121$ & 0 & $-0,2707$ & 0 & $-0,2542$ & 0 \\
\hline $\begin{array}{l}\text { Коефіцієнт фінансової незалежності в } \\
\text { частині формування запасів і витрат }\end{array}$ & 1,3376 & 0 & 1,0440 & 0 & 1,4884 & 0 \\
\hline Загальна кількість балів & & 4,8 & & 4 & & 4 \\
\hline
\end{tabular}

Джерело: розраховано авторами за даними [12].

Таким чином, результати аналізу фінансової стійкості за бальним методом продемонстрували, що ПРАТ «МК «АЗОВСТАЛЬ» у 2018-2020 рр. належить до $\mathrm{V}$ класу - кризове підприємство найвищого рівня ризику, практично не платоспроможне.

Також пропонується застосування інтегрального показника для оцінювання фінансової стійкості ПРАТ «МК «АЗОВСТАЛЬ». Фінансова стійкість залежить від багатьох показників, які потребують дослідження у взаємозв'язку. Методика оцінювання фінансової стійкості шляхом розрахунку інтегрального показника передбачає реалізацію кількох етапів (табл. 10).

Таблиця 10. Методика розрахунку інтегрального показника

Table 10. Methods of integrated indicator calculation

\begin{tabular}{|c|c|c|c|c|}
\hline Ч.ч. & Показник & $\begin{array}{c}\text { Ум. } \\
\text { позначення }\end{array}$ & Зміст показника & Формула розрахунку \\
\hline 1 & 2 & 3 & 4 & 5 \\
\hline 1 & $\begin{array}{c}\text { Складові матриці } \\
\text { стандартизованих } \\
\text { значень }\end{array}$ & $z_{i j}$ & $\begin{array}{c}\text { Дозволяє, позбутися від } \\
\text { одиниці виміру }\end{array}$ & $z_{i j}=\frac{x_{i j}-\bar{x} j}{S_{j}}$ \\
\hline 2 & $\begin{array}{c}\text { Середньо- } \\
\text { квадратичне } \\
\text { відхилення ј-го } \\
\text { показника }\end{array}$ & $\sigma_{j}$ & $\begin{array}{c}\text { Показує, на скільки в } \\
\text { середньому відхиляються } \\
\text { конкретні значення ознаки } \\
\text { від середнього значення. }\end{array}$ & $\sigma_{j}=\left[\frac{1}{w} \sum_{j=1}^{n}\left(x_{i j}-\overline{x_{j}}\right)^{2}\right]^{1 / 2}$ \\
\hline 3 & $\begin{array}{c}\text { Середнє значення } \\
\text { j-го показника }\end{array}$ & $\overline{x_{j}}$ & $\begin{array}{c}\text { Сума всіх фіксованих } \\
\text { значень набору, поділена } \\
\text { на кількість елементів } \\
\text { набору } \\
\end{array}$ & $\overline{x_{j}}=\frac{1}{w} \sum_{j=1}^{n} x_{i j}$ \\
\hline 4 & $\begin{array}{c}\text { Значення «точки- } \\
\text { еталону» }\end{array}$ & $Z_{i j}$ & $\begin{array}{c}\text { Еталонне значення } \\
\text { фактора стимулятора } \\
\text { або дестимулятора }\end{array}$ & $\begin{array}{c}Z_{i j}=\frac{x_{i j}}{x_{j \max }}-\text { для } \\
\text { стимуляторів; } \\
Z_{i j}=\frac{x_{j \text { max }}}{x_{i j}}-\text { для } \\
\text { дестимуляторів }\end{array}$ \\
\hline
\end{tabular}


Закінчення таблиці 10

\begin{tabular}{|c|c|c|c|c|}
\hline 1 & 2 & 3 & 4 & 5 \\
\hline 5 & Евклідова відстань & $c_{i o}$ & $\begin{array}{c}\text { Відстань між окремими } \\
\text { спостереженнями та } \\
\text { «точкою-еталоном» }\end{array}$ & $c_{i o}=\sqrt{\sum_{j=1}^{m}\left(Z_{i j}-Z_{o j}\right)^{2}}$ \\
\hline 6 & $\begin{array}{c}\text { Середня Евклідова } \\
\text { відстань }\end{array}$ & $\bar{C}_{0}$ & $\begin{array}{c}\text { Середня відстань між } \\
\text { спостереженнями }\end{array}$ & $\overline{C_{0}}=\frac{1}{w} \sum_{i=1}^{w} C_{i 0}$ \\
\hline 7 & $\begin{array}{l}\text { Стандартне } \\
\text { відхилення }\end{array}$ & $S_{0}$ & $\begin{array}{c}\text { Показник розсіювання } \\
\text { значень випадкової } \\
\text { величини відносно іiї } \\
\text { математичного очікування }\end{array}$ & $S_{0}=\sqrt{\frac{1}{w} \sum_{i=1}^{w}\left(C_{i 0}-\overline{C_{0}}\right)^{2}}$ \\
\hline 8 & $\begin{array}{c}\text { Максимально } \\
\text { можливе } \\
\text { відхилення від } \\
\text { зведеного еталону } \\
\end{array}$ & $C_{0}$ & $\begin{array}{c}\text { Характеризує } \\
\text { максимально можливе } \\
\text { відхилення від зведеного } \\
\text { еталону } \\
\end{array}$ & $C_{0}=\overline{C_{0}}+3 \times S_{0}$ \\
\hline 9 & Зведений еталон & $d$ & - & $d=\frac{C_{i 0}}{C_{0}}$ \\
\hline 10 & $\begin{array}{c}\text { Інтегральний } \\
\text { показник }\end{array}$ & $I_{i}$ & $\begin{array}{c}\text { Показник, що комплексно } \\
\text { характеризує фінансову } \\
\text { стійкість } \\
\end{array}$ & $I_{i}=1-d$ \\
\hline
\end{tabular}

Джерело: складено авторами на підставі [13].

По-перше, сформуємо систему інформаційного простору для розрахунку інтегрального показника фінансової стійкості. Наступний етап - це ранжування факторів на фактори-стимулятори та дестимулятори. Поділ проводимо за принципом впливу фактора на рівень фінансової стійкості. Фактори, що чинять позитивний вплив, відносимо до стимуляторів, фактори, що гальмують розвиток - до дестимуляторів. Отримані значення інтегрального показника фінансової стійкості ПРАТ «МК «АЗОВСТАЛЬ» наведено в табл. 11.

Таблиця 11. Отримані значення інтегрального показника фінансової стійкості

Table 11. The obtained values of the financial stability integrated indicator

\begin{tabular}{|l|c|c|c|c|}
\hline \multirow{2}{*}{ Показник } & \multicolumn{3}{c|}{ Значення за роками } & \multirow{2}{*}{ Стимулятор/ } \\
\cline { 2 - 4 } & 2018 & 2019 & 2020 & дестимулятор \\
\hline Коефіцієнт автономії (незалежності) & 0,3280 & 0,2964 & 0,3258 & Стимулятор \\
\hline Коефіцієнт концентрації залученого капіталу & 0,6720 & 0,7036 & 0,6742 & Дестимулятор \\
\hline Коефіцієнт фінансової стабільності & 0,4882 & 0,4213 & 0,4832 & Стимулятор \\
\hline Коефіцієнт фінансового ризику & 2,0485 & 2,3737 & 2,0696 & Дестимулятор \\
\hline Коефіцієнт фінансової стійкості & 0,3756 & 0,3505 & 0,3889 & Стимулятор \\
\hline Коефіцієнт структури залученого капіталу & 0,0709 & 0,0768 & 0,0936 & Стимулятор \\
\hline Коефіцієнт маневреності власного капіталу & $-0,0245$ & $-0,5056$ & $-0,4195$ & Стимулятор \\
\hline Коефіцієнт забезпеченості оборотних коштів & $-0,0121$ & $-0,2707$ & $-0,2542$ & Стимулятор \\
\hline Коефіцієнт забезпеченості запасів & $-0,0668$ & $-1,9990$ & $-1,9151$ & Стимулятор \\
\hline Коефіцієнт маневреності ВОК & $-1,1838$ & $-0,0325$ & $-0,1197$ & Стимулятор \\
\hline Коефіцієнт реальної вартості майна & 0,3951 & 0,4384 & 0,4843 & Стимулятор \\
\hline $\begin{array}{l}\text { Коефіцієнт реальної вартості основних } \\
\text { засобів у майні }\end{array}$ & 0,2746 & 0,3487 & 0,4130 & Стимулятор \\
\hline Коефіцієнт накопичення амортизації & 0,1936 & 0,0442 & 0,1250 & Сестимулятор \\
\hline Евклідова відстань & 4,4031 & 5,5226 & 3,0467 & \\
\hline $\begin{array}{l}\text { Значення інтегрального показника фінансової } \\
\text { стійкості }\end{array}$ & 0,3065 & 0,1301 & 0,1301 & \\
\hline
\end{tabular}

Джерело: розраховано авторами за даними [12]. 
Значення інтегрального показника чим ближче до 1, тим краще. У 2020 p. інтегральний показник фінансової стійкості збільшився. Для інтерпретації інтегрального показника використовується шкала Харрінгтона (табл. 12).

Таблиця 12. Числові інтервали значень інтегрального показника за шкалою бажаності Харрінгтона

Table 12. Numerical intervals of values of the integrated indicator on the Harrington scale of desirability

\begin{tabular}{|c|c|c|c|c|c|}
\hline Інтерпретація & Дуже погано & Погано & Задовільно & Добре & Відмінно \\
\hline $\begin{array}{c}\text { Інтервали } \\
\text { оцінок }\end{array}$ & $0-0,2$ & $0,2-0,37$ & $0,37-0,63$ & $0,63-0,8$ & $0,8-1$ \\
\hline
\end{tabular}

Джерело: побудовано авторами на підставі [14].

Таким чином, фінансова стійкість ПРАТ «МК «АЗОВСТАЛЬ» у 2018 р. $є$ поганою, у 2019 р. - дуже поганою, а в 2020 р. - задовільною. Однак варто запропонувати заходи щодо їі підвищення для своєчасного недопущення погіршання в майбутньому.

У межах покращення фінансової стійкості та відновлення платоспроможності в роботі пропонуються управлінські заходи, диференційовані для I, II та III типів фінансової стійкості (табл. 13).

Таблиця 13. Запропоновані управлінські заходи щодо підвищення фінансової стійкості та відновлення платоспроможності підприємства

Table 13. The proposed management measures for increasing financial stability and restore the enterprise solvency

\begin{tabular}{|c|c|c|c|}
\hline $\begin{array}{c}\text { Тип } \\
\text { стійкості }\end{array}$ & $\begin{array}{c}\text { Інтерпретація } \\
\text { інтегрального } \\
\text { показника }\end{array}$ & Характеристика & $\begin{array}{c}\text { Запропоновані управлінські заходи } \\
\text { щодо підвищення фінансової стійкості }\end{array}$ \\
\hline 1 & 2 & 3 & 4 \\
\hline I тип & $\begin{array}{c}\text { Добре } \\
\text { Відмінно }\end{array}$ & $\begin{array}{c}\text { Достатній рівень } \\
\text { ліквідності та } \\
\text { платоспроможності. } \\
\text { Явних загроз щодо } \\
\text { погашення } \\
\text { заборгованостей } \\
\text { немає }\end{array}$ & $\begin{array}{l}\text { - Оптимізація збутової політики за рахунок } \\
\text { забезпечення високої якості продукції та вста- } \\
\text { новлення ціни, нижчої за середньогалузеву; } \\
\text { розширення ринків збуту. } \\
\text { - Реалізація зайвих виробничих і невиробничих } \\
\text { фондів, здавання ї в оренду, що дозволяє } \\
\text { збільшити грошові кошти на рахунку підприємства, } \\
\text { як наслідок, підвищити його ліквідність і } \\
\text { дозволить залучати довго- і короткотермінові } \\
\text { позики в банку для фінансування поточної } \\
\text { діяльності. } \\
\text { - розроблення та виробництво нових видів } \\
\text { продукції, що дасть змогу стабілізувати й } \\
\text { покращити фінансовий стан підприємства. } \\
\text { Підвищувати рівень конкурентоспроможності } \\
\text { продукції та послуг. Здійснювати ефективну } \\
\text { маркетингову політику та забезпечувати лояльність } \\
\text { своїх клієнтів і партнерів }\end{array}$ \\
\hline
\end{tabular}


Закінчення таблиці 13

\begin{tabular}{|c|c|c|c|}
\hline 1 & 2 & 3 & 4 \\
\hline II тип & Задовільно & $\begin{array}{c}\text { Середній рівень } \\
\text { ліквідності та } \\
\text { платоспроможності. } \\
\text { Проблеми } \\
\text { ліквідності. } \\
\text { Найбільш термінові } \\
\text { зобов’язання здатні } \\
\text { погашати, але для } \\
\text { погашення більш } \\
\text { тривалих } \\
\text { зобов'язань } \\
\text { існують ризики } \\
\end{array}$ & $\begin{array}{l}\text { - Пошук оптимального співвідношення власного й } \\
\text { позикового капіталу, що дозволить забезпечити } \\
\text { мінімальний фінансовий ризик за максимальної } \\
\text { рентабельності власного капіталу. } \\
\text { - Упровадження оперативного механізму фінансової } \\
\text { стабілізації, спрямованої на зменшення фінансових } \\
\text { зобов'язань та збільшення грошових активів, що } \\
\text { забезпечують ці зобов'язання, з метою оптимізації } \\
\text { ліквідності. } \\
\text { - Нівелювання за допомогою різноманітних удоско- } \\
\text { налень технологій, модернізацій і автоматизацій } \\
\text { виробництва. }\end{array}$ \\
\hline III тип & $\begin{array}{c}\text { Погано } \\
\text { Дуже погано }\end{array}$ & $\begin{array}{c}\text { Низький рівень } \\
\text { ліквідності та } \\
\text { платоспроможності. } \\
\text { Є проблеми з } \\
\text { формуванням } \\
\text { власного } \\
\text { оборотного } \\
\text { капіталу }\end{array}$ & $\begin{array}{l}\text { - Здійснювати покращення планування фінансових } \\
\text { потоків, вводити у дію реальні платіжні календарі, } \\
\text { створювати центри фінансової відповідальності, що } \\
\text { дозволить завжди мати в наявності достовірну } \\
\text { інформацію про грошові потоки підприємства та } \\
\text { підвищити контрольованість поточних платежів, } \\
\text { знизити втрати від нецільового використання коштів } \\
\text { та забезпечити прозорість діяльності. } \\
\text { - Пришвидшення оборотності ресурсів підприємства } \\
\text { та зменшення терміну іх обороту, що покращить } \\
\text { загальну ефективність діяльності. Якісно підви- } \\
\text { щувати структуру виробництва, насамперед, } \\
\text { коефіцієнтів завантаженості та оборотності шляхом } \\
\text { збільшення обсягу продукції, а також забезпечувати } \\
\text { зменшення тривалості операцій-ного та фінансового } \\
\text { циклу. У свою чергу, це дозволить зменшити обсяг } \\
\text { залучених зовнішніх ресурсів. } \\
\text { - Відновлення здатності до здійснення платежів за } \\
\text { своїми невідкладними фінансовими зобов’язаннями з } \\
\text { метою попередження виникнення процедури бан- } \\
\text { крутства. } \\
\text { - Нівелювати неплатоспроможність суб'єкта госпо- } \\
\text { дарювання за рахунок зміни фінансової стратегії, що } \\
\text { дозволить якісно здійснити прискорення економіч- } \\
\text { ного зростання підприємства }\end{array}$ \\
\hline
\end{tabular}

Джерело: розроблено авторами на підставі $[2,10]$.

Висновки. Здійснено оцінювання фінансової стійкості металургійного підприємства за коефіцієнтним, бальним та інтегральним методами. За бальним методом воно належить до V класу - кризове підприємство найвищого рівня ризику, практично не платоспроможне. За інтегральним методом металургійне підприємство віднесено до III класу, для якого запропоновано здійснювати покращення планування фінансових потоків, вводити у дію реальні платіжні календарі, що дозволить завжди мати достовірну інформацію про грошові потоки підприємства та підвищити контрольованість поточних платежів, знизити втрати від нецільового використання коштів. Також запропоновано пришвидшення оборотності ресурсів підприємства, якісне підвищення структури виробництва, насамперед коефіцієнтів завантаженості та оборотності шляхом збільшення обсягу продукції, а також забезпечення зменшення тривалості операційного та фінансового циклів. У свою чергу, це дозволить зменшити обсяг залучених зовнішніх ресурсів і підвищити фінансову стійкість підприємства. 
Conclusions. The financial stability of the metallurgical enterprise is evaluated according to coefficient, scoring and integrated approaches. According to the scoring method, it belongs to $\mathrm{V}$ class, i.e. crisis enterprise of the highest level of risk, practically insolvent. According to the integrated method, the metallurgical enterprise is classified in III class, for which it is proposed to improve the financial flows planning, put into operation real payment calendars, which will always have reliable information about cash flows and increase control over current payments, reduce losses from misuse. It is also proposed to accelerate the turnover of enterprise resources, qualitatively increase the structure of production, primarily load factors and turnover by increasing production, as well as reducing the duration of operating and financial cycles. In turn, this will reduce the amount of involved external resources and increase the enterprise financial stability.

\section{Список використаної літератури}

1. Татар М. С. Ідентифікація та класифікація глобальних викликів. Часопис економічних реформ. 2020. № 3 (39). С. 36-44.

2. Геращенко I. О., Войтенко А. Ю. Інноваційні методи управління фінансовою стійкістю підприємства. Вісник економіки транспорту і промисловості. 2012. С. 137-142.

3. Гізатулліна О. М. Фінансова стійкість підприємства: економічна сутність та методика оцінки. Прометей. 2018. № 2. С. 239-244.

4. Слецьких С. Я. Послідовність етапів процесу управління розвитком промислового підприємства 3 позицій забезпечення його фінансової стійкості. Науковий огляд. 2014. Т. 8. № 9. С. 41-57.

5. Копчак Ю. С. Проблеми діагностики фінансового стану і стійкості функціонування підприємства. Вісник Сумського державного університету. 2019. № 9. С. 23-34.

6. Косарєва І. П. Удосконалення системи управління фінансовою стійкістю підприємств. Глобальні та національні проблеми економіки. 2018. № 23. С. 246-251.

7. Патута О. С., Пришко К. Є. Вплив структури капіталу на фінансову стійкість підприємства. Економіка і суспільство. 2018. № 2. С. 323-327.

8. Поддєрьогін А. М., Наумова Л. Ю. Фінансова стійкість підприємств в економіці України: монографія. К.: КНЕУ, 2016. 184 с.

9. Притуляк Н. М. Ознаки фінансової стійкості - теоретична основа моделювання факторних систем. Економіка. Фінанси. Право. 2018. № 1. С. 26-31.

10. Рудницька О. М., Біленська Я. Р. Шляхи покращення фінансового стану українських підприємств. URL: http://ena.lp.edu.ua:8080/bitstream/ntb/2700/1/19.pdf.

11. Тридід О. М., Орєхова К. В. Оцінювання фінансової стійкості підприємства: монографія. К.: Вид-во Університету БС НБ України, 2017. 143 с.

12. Офіційний сайт ПРАТ «МК «АЗОВСТАЛЬ». URL: https://azovstal.metinvestholding.com/ru.

13. Плюта В. Сравнительный многомерный анализ в экономических исследованиях: методы таксономии и факторного анализа / пер. с пол. В. В. Иванова; науч. ред. В. М. Жуковской. М.: Статистика, 1980. $151 \mathrm{c}$.

14. Harrington E. C. The Desirability Function. Industrial Quality Control. 1965. April. P. 494-498.

\section{References}

1. Tatar M. S. (2020) Identyfikatsiia ta klasyfikatsiia hlobalnykh vyklykiv [Identification and classification of global challenges]. Chasopys ekonomichnykh reform. No. 3 (39). P. 36-44.

2. Herashchenko I. O. Voitenko A. Iu. (2012) Innovatsiini metody upravlinnia finansovoiu stiikistiu pidpryiemstva [Innovative methods of managing the financial stability of the enterprise]. Visnyk ekonomiky transportu i promyslovosti. P. 137-142.

3. Hizatullina O. M. (2018) Finansova stiikist pidpryiemstva: ekonomichna sutnist ta metodyka otsinky [Enterprise financial stability: economic essence and methods of assessment]. Prometei. No. 2. P. 239-244.

4. Ieletskykh S. Ia. (2014) Poslidovnist etapiv protsesu upravlinnia rozvytkom promyslovoho pidpryiemstva z pozytsii zabezpechennia yoho finansovoi stiikosti [The sequence of stages of the process of managing the development of an industrial enterprise from the standpoint of ensuring its financial stability]. Naukovyi ohliad. No. 9. P. 41-57.

5. Kopchak Yu. S. (2019) Problemy diahnostyky finansovoho stanu i stiikosti funktsionuvannia pidpryiemstva. Visnyk Sumskoho derzhavnoho universytetu. No. 9. P. 23-34. 
6. Kosarieva I. P. (2018) Udoskonalennia systemy upravlinnia finansovoiu stiikistiu pidpryiemstv [Improving the management system of financial stability of enterprises]. Hlobalni ta natsionalni problemy ekonomiky. No. 23. P. 246-251.

7. Patuta O. S., Pryshko K. Ie. (2018) Vplyv struktury kapitalu na finansovu stiikist pidpryiemstva. [The impact of capital structure on the enterprise financial stability]. Ekonomika i suspilstvo. No. 2. P. 323-327.

8. Poddierohin A. M., Naumova L. Iu. (2016) Finansova stiikist pidpryiemstv v ekonomitsi Ukrainy [Financial stability of enterprises in the economy of Ukraine]: monohrafiia. K.: KNEU, 184 p.

9. Prytuliak N. M. (2018) Oznaky finansovoi stiikosti - teoretychna osnova modeliuvannia faktornykh system [Signs of financial stability - the theoretical basis for modeling factor systems]. Ekonomika. Finansy. Pravo. No. 1. P. 26-31.

10. Trydid O. M., Oriekhova K. V. (2017) Otsiniuvannia finansovoi stiikosti pidpryiemstva [Assessment of financial stability of the enterprise]: Monohrafiia. K.: Vyd-vo Universytetu BA NBU, 143 p.

11. Rudnytska O. M., Bilenska Ya. R. Shliakhy pokrashchennia finansovoho stanu ukrainskykh pidpryiemstv. URL: http://ena.lp.edu.ua:8080/bitstream/ntb/2700/1/19.pdf.

12. Ofitsiinyi sait PRAT “MK “AZOVSTAL”. URL: https://azovstal.metinvestholding.com/ru.

13. Pliuta V. (1980) Sravnytelnyi mnohomernyi analyz v ekonomycheskykh yssledovanyiakh: metody taksonomyy y faktornoho analyza [Comparative multidimensional analysis in economic research: methods of taxonomy and factor analysis] / per. s pol. V. V. Yvanova; nauch. red. V. M. Zhukovskoi. M.: Statystyka, $151 \mathrm{p}$.

14. Harrington E. C. The Desirability Function. Industrial Quality Control. 1965. April. P. 494-498. 